\title{
The Influence of Personal Factors of the Patient, Doctor, Payment Method and Type of Class to the Quality and Satisfaction of Inpatient Care Services in Dr. Moewardi Hospital Surakarta
}

\author{
Prima Soultoni Akbar 1), Rita Benya Adriani 2), Bhisma Murti 1) \\ ${ }^{1)}$ Masters Program of Public Health, Sebelas Maret University, Surakarta \\ ${ }^{2)}$ School of Health Polytechnics, Surakarta
}

\begin{abstract}
Background: The quality of hospital care is an important element in the implementation of healthcare service. The quality which is perceived is an assessment and a form of evaluation of healthcare users. Improvement on healthcare service is continually conducted to enhance the quality of service and patients' satisfaction. The study aimed to explain the influence of patients' personal factors, doctors, payment methods and types of class toward the quality and satisfaction of inpatient care.

Subjects and Methods: This was an analytic observational study with cross-sectional design. This study was conducted at Dr. Moewardi Hospital, Surakarta, from March to April 2017. A total of 144 subjects were selected by stratified random sampling. Exogenous variables in this study were family income, level of education, length of stay, doctor's salary, the surgeon, type of insurance, and type of class. Endogenous variables were patient's satisfaction and quality of service. The data were collected by a set of questionnaires and secondary data of doctor's working period and salary. Data analyzed by path analysis.

Results: Patient's satisfaction were affected by family income ( $b=-0.08 ; \mathrm{SE}=0.48 ; \mathrm{p}=0.093$, level of education $(b=-0.44 ; \mathrm{SE}=0.27 ; \mathrm{p}=0.102)$, length of stay $(\mathrm{b}=0.19 ; \mathrm{SE}=0.99 ; \mathrm{p}=0.059)$, doctor's salary $(b=0.02 ; S E=0.01 ; p=0.060)$, doctor's working period $(b=0.99 ; S E=0.44 ; p=0.024)$, type of insurance $(b=0.72 ; \mathrm{SE}=0.32 ; \mathrm{p}=0.027)$, type of class $(\mathrm{b}=2.11 ; \mathrm{SE}=0.38 ; \mathrm{p}<0.001)$, and quality of health services $(b=0.16 ; \mathrm{SE}=0.51 ; \mathrm{p}=0.002)$. Quality of health services were affected by family income $(b=-0.15 ; \mathrm{SE}=0.07 ; \mathrm{p}=0.039)$, length of stay $(\mathrm{b}=0.37 ; \mathrm{SE}=0.15 ; \mathrm{p}=0.017)$, doctor's working period $(b=0.13 ; \mathrm{SE}=0.68 ; \mathrm{p}=0.056)$, insurance types $(\mathrm{b}=1.04 ; \mathrm{SE}=0.50 ; \mathrm{p}=0.036)$, and type of class $(b=2.24 ; \mathrm{SE}=0.59 ; \mathrm{p}<0.001)$.

Conclusion: Patient's satisfaction are affected by family income, level of education, length of stay, doctor's salary, doctor's working period, type of insurance, type of class and quality of health services. Quality of health services are affected by family income, length of stay, doctor's working period, insurance types, and type of class.
\end{abstract}

Keywords: quality of health services, patient's satisfaction

\section{Correspondence:}

Prima Soultoni Akbar. Masters Program of Public Health, Sebelas Maret University, Surakarta. Email: primasoultoniakbar@gmail.com. Mobile: +6285258777994.

\section{BACKGROUND}

Health system is an important matter within a country. National Healthcare System is a management of healthcare organized by all components of the nation in integrated and inter dependent manner in order to ensure the accomplishment of community health status as high as possible (Permen- kes RI, 2016). Healthcare system is beneficial to fulfill the needs of healthcare of individual, family, group, and community. The purpose of healthcare system is to establish good healthcare service, responsive toward communities' expectation and owns equitable financial contribution (WHO, 2009). 
Journal of Health Policy and Management (2017), 2(1): 1-15

https://doi.org/10.26911/thejhpm.2017.02.01.01

Improvements in healthcare service are recurrently conducted to increase the quality of service and patient's satisfaction. Patients' satisfaction is positively associated with the quality assessment of a healthcare service (Anjaryani, 2009)

Hospital is one form of public healthcare service that should improve its service toward excellent service. Excellent service is a service that give good even the best service based on customer oriented or customer focus (Irawati and Primadha, 2008; Nurfauzi, 2013). To give excellent service means it is not allowed to conduct any form of discrimination (discrimination based on ethnic group, race, group, religion, social status, payment method and others (Sinambela, 2006). Along with the improving condition of civil society, the people awareness toward healthcare service quality is also improving (Faizin et al., 2015).

According to the result of previous studies, in developing countries, patients' satisfaction is used as the yardstick of healthcare service quality. The consequence of patients' dissatisfaction toward healthcare service among others are: not following the medical procedures well, not conducting follow-up examination, and even emerging negative rumors that influence users of the healthcare service. Healthcare service which is oriented to doctors' personal factors is discovered to have strong influence toward patients' satisfaction at the hospital (Andaleeb et al., 2007).

Factors which influence patients' satisfaction, among others are: reliability, assurance, responsiveness, tangibility of physical service and empathy. Reliability refers to the ability of healthcare service providers to give reliable and accurate services. Responsiveness means that health workers is responsive to patients' needs, accuracy in diagnosing patients, the condition of instru- ments availability, and the completeness of medicines needed (Andaleeb et al., 2007).

Knowledge, skills and good manner of healthcare workers give the sense of convinced on assurance to the patients. The assurance can be in a form of healthcare workers who are competent in diagnosing, interpreting the result of examination. The sense of assurance may generate patients' satisfaction. The bigger patients' conviction toward the assurance is, the higher patients' satisfaction will be (Andaleeb et al., 2007).

Good tangibility of physical facilities such as equipments, hospitals' occupational hygienists, toilets, examination rooms, wards, and beds may influence patients' impression toward the hospital. The better tangibility of healthcare service facilities and providers is, the higher patients' satisfaction will be (Andaleeb et al., 2007).

Empathy and understanding of healthcare workers on patients' problem and needs can intensely influence patients' satisfaction. Personal care and psychological support reflect the empathy service of healthcare service providers. The bigger empathy obtained by the patients is, the bigger patients' satisfaction will be (Andaleeb et al., 2007).

In addition to service factors, cost of care is another factor that influences patients' satisfaction. Based on the result of some studies in developing countries, cost is one of considerations in looking for healthcare service, moreover, for low income patients. Healthcare service cost in this matter includes cost for consultation, laboratory tests, medicines and accommodation. Some countries even have provided primary healthcare service for free through the existence of health insurance system. The description shows that patients' perception toward expensive cost for health- 
care service may decline patients' satisfaction (Andaleeb et al., 2007).

The study aimed to analyze the influence of patients' personal factors, doctors, payment method and types of class toward the quality and satisfaction of inpatient care in RSUD Dr. Moewardi, Surakarta.

\section{SUBJECTS AND METHODS \\ 1. Research Design \\ The type of the study was analytic obser- vational with cross sectional design. The study was conducted from March to April 2007 in RSUD Dr. Moewardi, Surakarta.}

\section{Population and Sample}

The subject of the study were patients of inpatient ward with type of class I, II, III of RSUD Dr. Moewardi, Surakarta. The inclusion criteria of the study was inpatient care patients who are older than 17 years old. There were a total of 144 subjects of the study who were selected using stratified random sampling with probability sampling.

\section{Research Variables}

Exogenous variables in the study were family income, patients' level of education, length of stay, doctors' salary, type of insurance and type of class of inpatient ward.
Endogenous variables were healthcare service quality and patients' satisfaction.

The quality of care was evaluated based on patients' personal factors, doctors' personal factors, payment method and hospital types of class. Patients' personal factor was evaluated from level of education, family income, and length of stay. Doctors' personal factors include doctor's working period, and doctors' salary. Patients' payment method to hospital was evaluated based on patients' insurance status that consists of non insurance, Self-reliance National Healthcare Security (BPJS Mandiri), National Healthcare Security for Company (BPJS Perusahaan) and Aid Recipient (PBI)

\section{Data Analysis}

Data of service quality and patients' satisfaction were collected using questionnaires. A reliability test was conducted on the questionnaires to 15 inpatient care patients, before it was used in the study. Data of doctors' working period and the total of doctors' salary were obtained from secondary data observation. The data were analyzed using path analysis.

Table 1. The result of reliability test on questionnaires about healthcare service quality and patients' satisfaction

\begin{tabular}{clcc}
\hline No & \multicolumn{1}{c}{ Variables } & Item Total Correlation (r) & Cronbach's Alpha \\
\hline 1 & Tangible & $\geq 0.25$ & 0.87 \\
2 & Reliability & $\geq 0.35$ & 0.85 \\
3 & Responsiveness & $\geq 0.26$ & 0.84 \\
4 & Assurance & $\geq 0.34$ & 0.76 \\
5 & Empathy & $\geq 0.30$ & 0.73 \\
6 & Satisfaction & $\geq 0.29$ & 0.85 \\
\hline
\end{tabular}

\section{RESULTS}

\section{Univariate Analysis}

Univariate analysis included the characteristics of the subjects of the study and the variables of the study. The characteristics of the subjects of the study were explained in Table 3. Based on Table 2 most subjects of the study were patients of inpatient care who were $<40$ years old, that was 54 people (37.5\%). Majority of the subjects were male as many as 84 people (58.3\%). Most pa- 
Journal of Health Policy and Management (2017), 2(1): 1-15

https://doi.org/10.26911/thejhpm.2017.02.01.01

tients of inpatient care were high school/ vocational high school graduates, that was 39 people (27.1\%). There were 30 patients who were farmers (20.8\%). Most subjects of the study were patients of inpatient care whohad income $\geq$ Regional Minimum Wage (56.9\%). As many as 55 subjects of inpatients study (53.5\%) travelled $\leq 30 \mathrm{~km}$ from their homes to RSUD Dr. Moewardi, Surakarta.

Table 2. Characteristics of the subjects of the study

\begin{tabular}{llcc}
\hline \multicolumn{1}{c}{ Characteristics } & Criteria & n & \% \\
\hline Patients' age & < 40 years & 54 & 37.5 \\
& 41-50 years & 46 & 31.9 \\
& 51-60 years & 34 & 23.6 \\
Sex types & 6o years & 10 & 6.9 \\
& Male & 84 & 58.3 \\
& Female & 60 & 41.7 \\
& No School & 6 & 4.2 \\
& Primary & 16 & 11.1 \\
& Secondary & 25 & 17.4 \\
& High School/ Vocational High School & 39 & 27.1 \\
& Associate Degree & 35 & 24.3 \\
Occupation & Bachelor's Degree & 23 & 16.0 \\
& Unemployed & 24 & 16.7 \\
& Students & 13 & 9.0 \\
& Civil Servants/ Armed Force/ Police Department & 10 & 6.9 \\
& Private Employee & 22 & 15.3 \\
& Self Employed & 28 & 19.4 \\
& Farmer & 30 & 20.8 \\
& Others & 17 & 11.8 \\
Patients' Income & <Regional Minimum Wage & 62 & 43.1 \\
& 2 Regional Minimum Wage & 82 & 56.9 \\
& S 3o Km & 77 & 53.5 \\
& 31-6o Km & 38 & 26.4 \\
& >6o Km & 29 & 20.1 \\
\hline
\end{tabular}

Table 3. Descriptive analysis of the variables of the study

\begin{tabular}{lcccc}
\hline \multicolumn{1}{c}{ Variables } & Mean & SD & Minimum & Maximum \\
\hline Family Income & 18.56 & 8.15 & 5 & 49 \\
Length of Stay & 6.36 & 2.97 & 2 & 14 \\
Doctors' Salary & 57.19 & 27.66 & 40 & 126 \\
Doctors' Working Period & 11.79 & 6.73 & 1 & 28 \\
Quality of Care & 127.05 & 6.23 & 114 & 145 \\
Patients' satisfaction & 30.47 & 4.72 & 21 & 40 \\
\hline
\end{tabular}

Table 3 showed the descriptive analysis of the variables of the study which was described based on minimum and maximum value, mean, and deviation standard, each had relatively high disparity of data

\section{Bivariate Analysis}

Bivariate analysis was used to analyze the association between patients' income, patients' education, patients' length of stay, doctors' salary, doctors' working period, status of insurance, type of class and healthcare service quality toward patients' satisfaction. Table 4 showed the average of patients' satisfaction in RSUD Dr. Moewardi was categorized as satisfied and very satisfied. Chi Square test result showed patients' satisfaction had a significant association with education $(\mathrm{OR}=0.30 ; 95 \% \mathrm{CI}=$ 
0.14 to $0.64 ; \mathrm{p}=0.001)$, length of stay $(\mathrm{OR}=$ $3.00 ; 95 \% \mathrm{CI}=1.47$ to $6.14 ; \mathrm{p}=0.002)$, doctors' working period $(\mathrm{OR}=2.82 ; 95 \% \mathrm{CI}=$ 1.43 to $5.56 ; \mathrm{p}=0.003$ ), type of insurance $\mathrm{OR}=3.40 ; 95 \% \mathrm{CI}=1.53$ to $7.53 ; \mathrm{p}=0.002)$, Class I type toward class II and III (OR= $5.80 ; 95 \% \mathrm{CI}=2.54$ to $13.33 ; \mathrm{p}<0.001)$, Class III type toward class I and II $(\mathrm{OR}=$
$0.25 ; 95 \% \mathrm{CI}=0.12$ to $0.52 ; \mathrm{p}<0.001)$, dan and service quality $(\mathrm{OR}=6.62 ; 95 \% \mathrm{CI}=$ 3.31 to 16.55 ; $\mathrm{p}<0.001$ ). However patients' satisfaction had an insignificant with family income $(\mathrm{OR}=0.66 ; 95 \% \mathrm{CI}=0.34$ to1.30; $\mathrm{p}=0.228)$ and doctors' salary $(\mathrm{OR}=1.72$; $95 \% \mathrm{CI}=0.88$ to $3.36 ; \mathrm{p}=0.108$ )

Table 4. Bivariate analysis on factors that influence patients' satisfaction.

\begin{tabular}{|c|c|c|c|c|c|c|}
\hline \multirow[b]{2}{*}{ Variables } & \multicolumn{2}{|c|}{ Patients' Satisfaction } & \multirow[b]{2}{*}{ OR } & \multicolumn{2}{|c|}{$95 \% \mathrm{CI}$} & \multirow[b]{2}{*}{$\mathbf{p}$} \\
\hline & $\begin{array}{c}\text { Satified } \\
\text { n (\%) }\end{array}$ & $\begin{array}{c}\text { Very Satisfied } \\
\text { n (\%) }\end{array}$ & & $\begin{array}{l}\text { Lower } \\
\text { Limit }\end{array}$ & $\begin{array}{l}\text { Upper } \\
\text { Limit }\end{array}$ & \\
\hline \multicolumn{7}{|l|}{ Family Income } \\
\hline $\begin{array}{l}<\text { Regional } \\
\text { Minimum Wage }\end{array}$ & $24(38.7 \%)$ & $38(61.3 \%)$ & 0.66 & 0.34 & 1.30 & 0.228 \\
\hline $\begin{array}{l}\geq \text { Regional } \\
\text { Minimum Wage }\end{array}$ & $40(48.8 \%)$ & $42(51.2 \%)$ & & & & \\
\hline \multicolumn{7}{|l|}{ Education } \\
\hline$<$ High School & $12(25 \cdot 5 \%)$ & $35(74.5 \%)$ & 0.30 & 0.14 & 0.64 & 0.001 \\
\hline$\geq$ High School & $52(53.6 \%)$ & $45(46.4 \%)$ & & & & \\
\hline \multicolumn{7}{|l|}{ Length of Stay } \\
\hline$<7$ days & $48(54.5 \%)$ & $40(45.5 \%)$ & 3.00 & 1.47 & 6.14 & 0.002 \\
\hline$\geq 7$ days & $16(28.9 \%)$ & $40(71.4 \%)$ & & & & \\
\hline \multicolumn{7}{|l|}{ Doctors' salary } \\
\hline$<5.8$ million & $39(50.6 \%)$ & $38(49.4 \%)$ & 1.72 & 0.88 & 3.36 & 0.108 \\
\hline$\geq 5.8$ million & $25(37.3 \%)$ & $42(62.7 \%)$ & & & & \\
\hline \multicolumn{7}{|c|}{ Doctors' working period } \\
\hline$<12$ years & $41(56.9 \%)$ & $31(43.1 \%)$ & 2.82 & 1.43 & $5 \cdot 56$ & 0.003 \\
\hline$\geq 12$ years & $23(31.9 \%)$ & $49(68.1 \%)$ & & & & \\
\hline \multicolumn{7}{|c|}{ Type of Insurance } \\
\hline No Insurance & $24(66.7 \%)$ & $12(33.3 \%)$ & 3.40 & 1.53 & 7.53 & 0.002 \\
\hline Insurance & $40(37,0 \%)$ & $68(63.0 \%)$ & & & & \\
\hline \multicolumn{7}{|c|}{ Type of Class I toward class II dan III } \\
\hline Class I & $9(18.8 \%)$ & $39(81.3 \%)$ & 5.8 & 2.54 & 13.33 & $<0.001$ \\
\hline Class II dan III & $55(57 \cdot 3 \%)$ & $41(42.7)$ & & & & \\
\hline \multicolumn{7}{|c|}{ Type of Class III toward class I dan II } \\
\hline Class I dan II & $32(33 \cdot 3 \%)$ & $64(66.7)$ & 0.25 & 0.12 & 0.52 & $<0.001$ \\
\hline Class III & $32(33 \cdot 3 \%)$ & $16(26.7)$ & & & & \\
\hline \multicolumn{7}{|l|}{ Quality of service } \\
\hline Good & $52(64.2 \%)$ & $29(35.8 \%)$ & 6.62 & $3 \cdot 51$ & 16.55 & $<0.001$ \\
\hline Very good & $12(19.0 \%)$ & $51(81.0 \%)$ & & & & \\
\hline
\end{tabular}

\section{Path Analysis}

\section{a. Model Specification}

Model specification illustrates the relationship among variables being studied. Observed variables in this study included family income, patients' education, length of stay, doctors' salary, doctors' working period, type of insurance, and type of class to- ward quality of service and patients' satisfaction.

\section{b. Model Identification}

Observed variables toward patients' satisfaction:

1) Number of observed variables $=9$

2) Endogenous Variables $=2$

3) Exogenous Variables $=7$ 
Journal of Health Policy and Management (2017), 2(1): 1-15

https://doi.org/10.26911/thejhpm.2017.02.01.01

4) Number of Parameters $=34$ follow

Degree of freedom formula, is as $\mathrm{df}=$ (number of observed variables $\mathrm{x}$ (number of observed variables +1 )) $/ 2-$ (endogenous variables + exogenous variables + number of parameter)

$$
\begin{aligned}
& =(9 \times(9+1)) / 2-(2+7+34) \\
& =45-43 \\
& =2
\end{aligned}
$$

Result of degree of freedom (df) was 2 it means over identified or path analysis was possible to conduct.

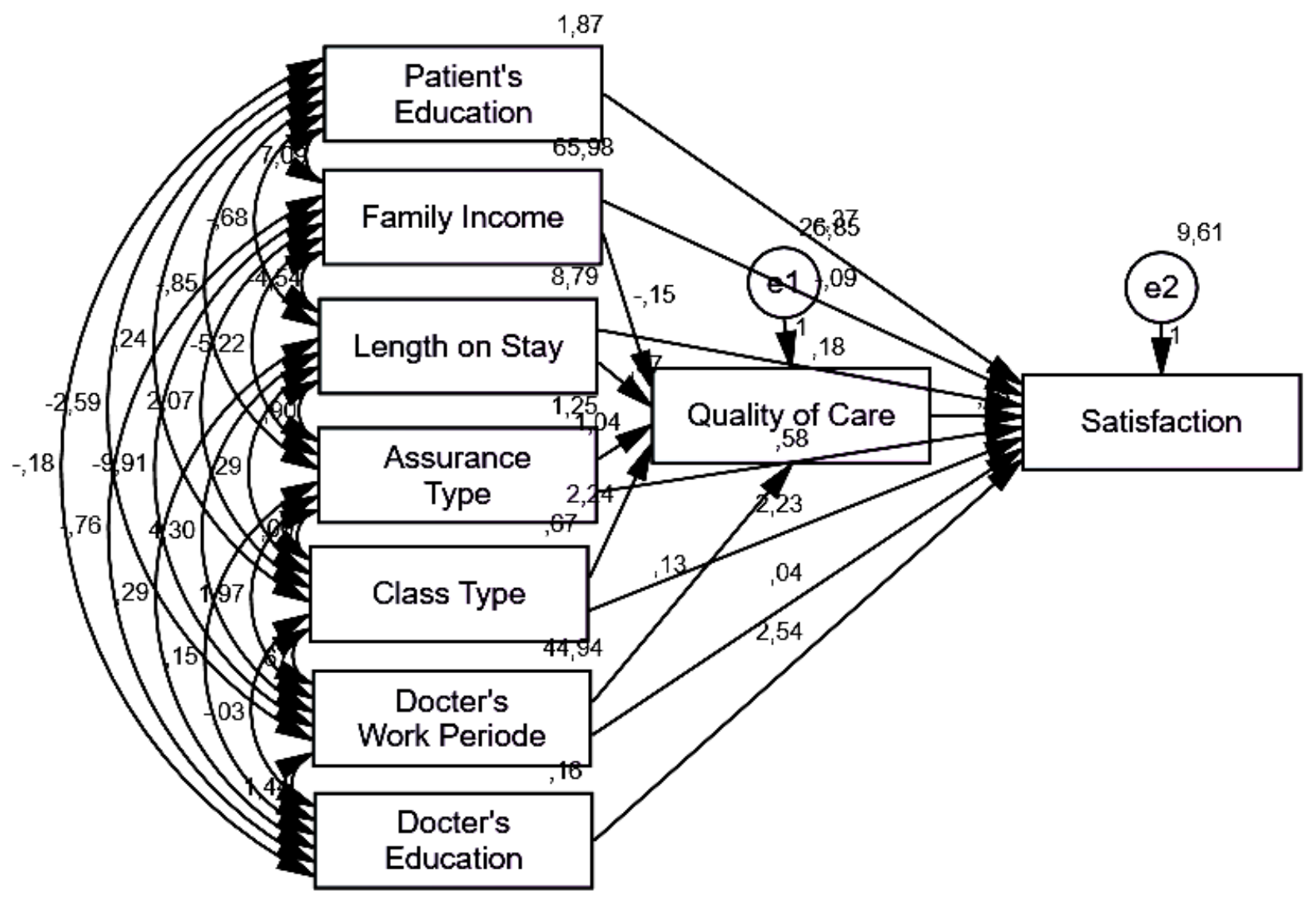

Picture 1. Structural model of path analysis with estimate.

Picture1shows structural models after estimation was made by using SPSS Amos program. Indicators that showed model conformity in Figure 1 was the result of CMIN fit index (Normed Chi Square) as much as 1.835 with $\mathrm{p}=0.399>0.05$; NFI (Normed Fit Index) $=0.99 \geq 0.90 ; \mathrm{CFI}$ (Comparative Fit Index) $=1.00 \geq 0.90$; GFI (Goodness of Fit Index) $=0.99 \geq 0.90$; RMSEA (Root Mean Square Error of Approximation) $<0.001 \leq 0.08$.

The value showed that the model fitted the criteria that were determined and confirmed as in accordance with empirical data. Patients' satisfaction was influenced by family income, patients' level of education, length of stay, doctors' salary, doctors' working period, type of insurance, type of class and quality of healthcare service.

Each unit of increase in family income would decrease the score of inpatient care patients' satisfaction by 0.o8. Each unit of increase in education level would decrease the score of inpatient care patients' satisfaction by 0.44 . Each unit of increase in length of stay would increase the score of inpatient care patients' satisfaction by 0.19 . 
Table 5. The result of path analysis on the influence of patients' personal factors, payment method, and type of class toward service quality and satisfaction

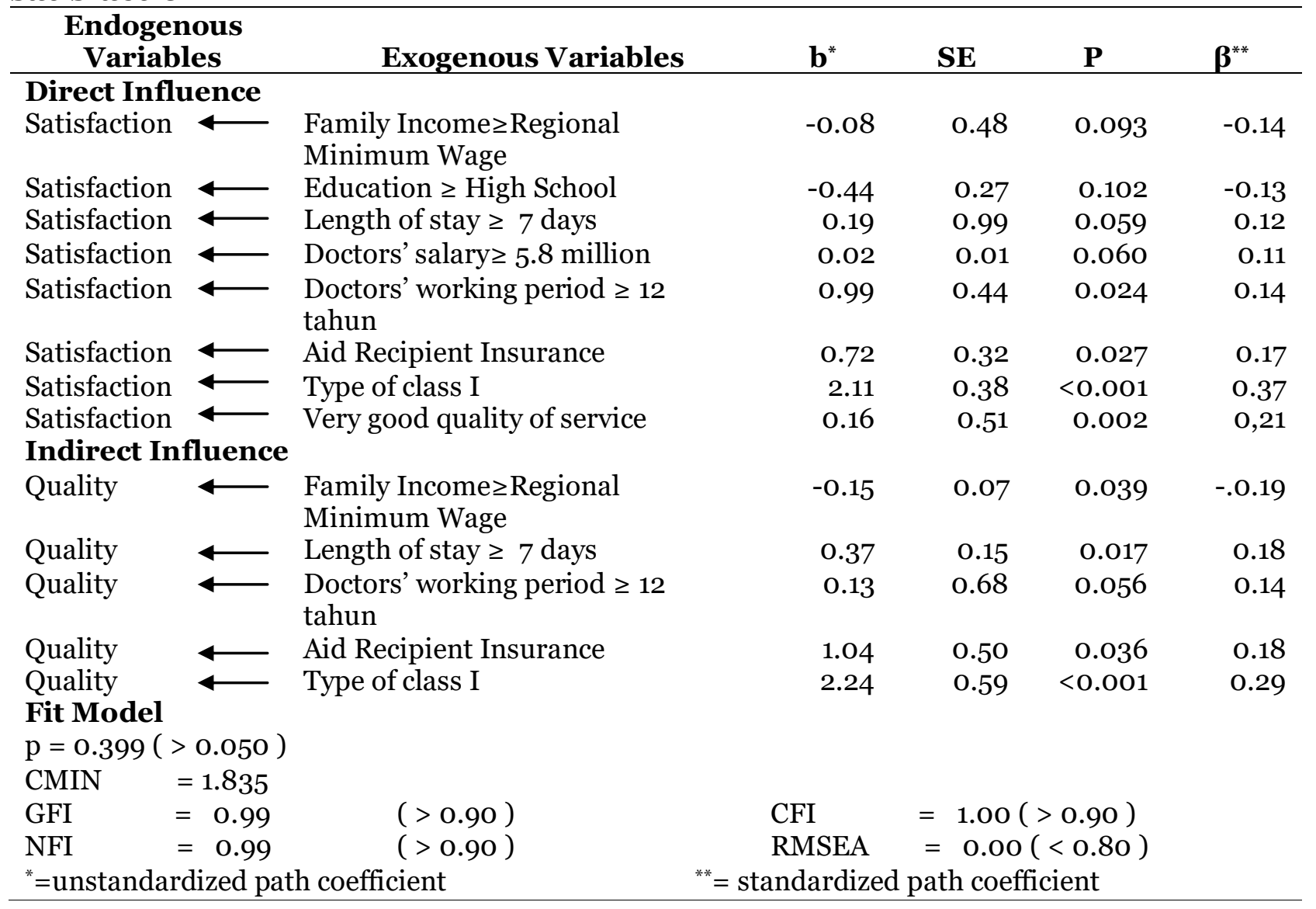

Each unit of increase in doctors' salary would increase the score of inpatient care patients' satisfaction by 0.02. Each unit of increase in doctors' working period would increase the score of inpatient care patients' satisfaction by 0.99. Each unit of increase in type of insurance would increase the score of inpatient care patients' satisfaction by 0.72 . Each unit of increase in type of class would increase the score of inpatient care patients' satisfaction by 2.11 . Each unit of increase in service quality would increase the score of inpatient care patients' satisfaction by 0.16 .

Quality of service was influenced by family income, length of stay, doctors' working period, type insurance and type of class. Each unit of increase in family income would decrease the score of inpatient care servicequality by 0.15 . Each unit of increase in length of stay would increase the score of inpatient care service quality by 0.37 . Each unit of increase in doctors' working period would increase the score of inpatient care servicequality by 0.13 . Each unit of increase in type of insurance would increase the score of inpatient care service quality by 1.04. Each unit of increase in type of class would increase the score of inpatient care service quality by 2.24 .

\section{DISCUSSION}

\section{A. The influence of family income toward patients' satisfaction.}

The result of path analysis of the study showed that there was a directly negative association between family income and in- 
Journal of Health Policy and Management (2017), 2(1): 1-15

https://doi.org/10.26911/thejhpm.2017.02.01.01

patient care patients' satisfaction in RSUD Dr. Moewardi and statistically significant.

It is in accordance with the result study of Haviland et al., (2005) that states low social economy status will influence patients' satisfaction and ability to buy care service is influenced by patients' income. Someone with high income is likely to be outspoken to question additional treatment to be conducted for the sake of health improvement and the disease suffered, in contrast someone with low income will be passive and will not question much and tends to accept well whatever treatment to be implemented. Anjaryani (2009) states that the demand for additional treatment will influence patients's satisfaction so that someone with high income is likely to be unsatisfied with condition of care and type of service given by the hospital.

The result of the study is supported by Khuong dan Anh (2013) that someone with high income is likely to have higher needs for services. Healthcare service provider needs to effectively improve the service capacity which is needed and meets the patients' expectation to improve patients' satisfaction. A good and integrated service is expected to give output in a form of patients' satisfaction for the performance of healthcare service providers in this term is hospitals. In reality, the fulfillment of service for the sake of patients' recovery is not met by the hospital thus leads to dissatisfaction out of patients' expectation (Deng et al., 2009).

The result of the study showed indirect negative association between family income by means of quality of service toward the patients satisfaction of inpatient care in RSUD Dr. Moewardi, Surakarta and statistically significant. It is in accordance with Kawachi et al., (2010) who states that income, wealth is used to attain better health or for health improvement. People with low income are likely to have limited options in the quality of healthcare service. Meanwhile those with high income will choose class with good standard of quality (Bravema et al, 2011).

\section{$B$. The influence of level of education toward patients' satisfaction.}

The result of the study showed that there was negative association between level of education with patients' satisfaction of inpatient care in RSUD Dr. Moewardi, however it is statistically insignificant. The result of the study is in accordance with Bakar et al., (2008) in Dengjuin et al., (2009) that patients with high level of education possess higher expectation and intention compared to those with low income. High expectation tends to make patient unsatisfied with healthcare service. Someone with higher education level can not adjust their expectation with the condition of hospital so that they need higher quality of service to make them feel satisfied. Patients with lower level of education have lower expectation so that they can adjust their expectation in accordance with the condition of hospital as well as accept whatever service given (Fraihi et al., 2016).

The study is supported by Fletcher and Frisvol (2012) that higher education influence a variety of medical treatments conducted. The higher the education of a patient is, the higher intention, expectation and confidence of the patient will be toward any medical treatment conducted. Patients with higher education will be more critical and having higher demand. Being critical generates high expectation in term of obtained healthcare service and is likely to be incapable to accept services below the expectation thus decreases patients' level of satisfaction toward the services provided by hospital. On the contrary, low educated patients are likely to accept any treatment to be given to recover. Thus, patients with 
low education are more satisfied than patients with high education.

\section{The influence of patients' length of stay toward patients' satisfaction.}

The result of path analysis showed that therewas a directly positive association between the length of stay toward patients' satisfaction of inpatient care in RSUD Dr. Moewardi, Surakarta and statistically approaching to significant. It is in accordance with the study conducted by Borghans et al., (2012) that states there is no correlation between length of stay and patients' satisfaction. Borghans et al., (2012) in his study does not find any evidence that hospital with relative shorter length of stay (LOS) owns higher level of satisfaction. Length of stay by considering physicall condition, type of diseases being suffered as well as the improvement in medication, is determined by hospital's medical team or doctor. Length of stay does not only depend on type of diseases but is also influenced by other factors, such as patients' emotional and psychological condition in facing the disease, thus, patients with similar type of disease will not necessarily have similar length of stay.

The study is supported by Oroh et al., (2014) that length of stay for each patients is different since patient is influenced emotionally in enduring the disease being suffered, so that proper emotional approach will make patients finds their psychological and social needs which is not fulfilled during their sickness, and patient will feel better with their condition and it leads to patients' satisfaction (Krishnasamy et al., 2001). The finding shows that the main focus of care does not only depend on physical care however on how healthcare service providers are able to recognize patients' psychological condition.

The result of path analysis in this study also shows that there was a indirect positive correlation between length of stay by means of quality of service toward patients' satisfaction of inpatient care in RSUD Dr Moewardi, and statistically significant. A study by Anjaryani (2009) states that there is a correlation between length of stay and patients' satisfaction. Patients with longer range of care time are likely to be more familiar with medical personnel, both doctor and nurses. Familiarity influences patients' psychological condition, in which patients feel well cared for and listened for their problems. It makes patients feel satisfied with the quality of healthcare service. Strong personal and emotional connection between service providers and customers in this terms is patients has been proven to positively influence the level of patients' satisfaction toward type of service obtained (Boer et al., 2010).

Based on the description above, psychological relationship between medical personnel and patients is greatly needed in giving care to generate proper communication. In addition, to improve the quality of service, hospitals need to make an informative approach by describing health development by using simple language which is easy to understand to patients and family member (Mulyawan, 2015).

\section{The influence of doctors' salary toward patients' satisfaction.}

The result of path analysis of the study showed that there was a directly positive association between doctors' salary toward patients' satisfaction of inpatient care and statistically approaching to significant. It is in accordance with the study conducted by Bardach et al., (2014) that states doctors' salary is very effective in maximally improving the quality of doctors' performance. Excellent doctors' performance actively play important role in improving the result of patients' recovery, thus, it will increase patients' satisfaction. Performance impro- 
Journal of Health Policy and Management (2017), 2(1): 1-15

https://doi.org/10.26911/thejhpm.2017.02.01.01

vement based on the salary received or Pay for Performance ( $\mathrm{P} 4 \mathrm{P})$ is also supported by Roland dan Dudley (2015) who state that incentive extension will improve doctors' working quality in providing service.

Patients will feel satisfied whenever doctors perform maximal performance and capacity during recovery phase. Economy factor (doctors' welfare) plays an important role in improving doctors working satisfaction and the impact can be perceived by patients in a form of good and satisfying service.

\section{E. The influence of doctors' working period toward patients' satisfac- tion.}

The result of path analysis showed that therewas a directly positive association between doctors' working period and patients' satisfaction of inpatient care in RSUD Dr. Moewardi, Surakarta and statistically significant. It is in accordance with Kim et al., (2017) that the longer doctors' working period, the more increasing capacity and knowledge they have. Patients will feel satisfied if they are handled by doctors with sufficientcapacity and knowledge. The longer doctors' working period will increase the capacity in therapeutic communication that can explore patients' needs and desire. The opinion is supported by Krishnasamy et al., (2001) that capacity in communicating and delivering information is very important for all parties, both doctors and patients.

Good communication is needed between doctors and patients about the procedure used in the treatment so that patients and their family understand the condition of health problems. Patients who obtained information on treatment and prevention which meets the expectation in patients recovery, will feel satisfied. In addition, patients' ailment and questions should be responded as well as answered in complete and proper manner so that pa- tients and their family are absolutely convinced about the procedure to be conducted as well as the result obtained. Doctors' capacity along with doctors' working period will reduce fear or anxiety toward problems that may not occur (Kim et al., 2017).

The result of path analysis of the study showed that there was an indirect positive association between doctors' working period by means of quality of service toward patients' satisfaction of inpatient care in RSUD Dr Moewardi and statistically approaching to significant. The study is in accordance with Kurtz (2005) who states that working period is a factor that greatly determines a doctor's experience and capacity. Doctor' working period is total number of annual working hours, in which the longer doctors' working period, the more experience in using treatment mechanism well and properly, as well as coordinating and creating good communication with other healthcare professionals in improving the quality of service. Good coordination and communication between doctors and patients is also established based on the length of working period thus it is needed in improving service quality. The intended communication is communication using language and terminology which are easy to understand so that patients understand prior and post the administration of procedure (Herqutanto et al., 2011).

Calnan dan Rowe (2006) show that level of trust given by patients to healthcare service is greatly influenced by the quality of relationship between doctors and patients. The trust is obtained through good communication, in which the communication is not only conducted to patients but also to colleagues as well as other medical team. The purpose is to gain an understanding and agreement, to be able to give satisfaction to healthcare service recipients. Good communication can be established by 
means of doctors' experience and working period.

\section{F. The influence of health insurance toward patients' satisfaction.}

The result of path analysis showed that there is a directly positive association between type of insurance toward patients' satisfaction of inpatient care in RSUD Dr Moewardi, Surakarta and statistically significant.

The use of health insurance in Indonesia is still controversial. It is generated by the status of insurance users which is not clear especially state-own insurance, that leads to the reluctance of service providers in giving the rights of insurance holders. Different result is conveyed by McMichael and Healy (2017) in the literature review in some South East Asia Countries (Cambodia, Laos, Myanmar, Thailand, Vietnam) that states there is no difference of insurance use in using quality healthcare service neither difference in the equality of healthcare service, both for insurance users and self-reliance or out- of pocket.

In order to fulfill public healthcare service in Indonesia, government launched a healthcare programs one of them is Social Health Insurance (Jamkesmas), however according to Dwiyanto (2010), the existence of Jamkesmas is still covered with problems in terms of service delivery. It is because of the status of health insurance which still becomes a consideration in delivering healthcare service thus people who are registered in Jamkesmas do not use their rights properly. They prefer to use healthcare service as general users than using their right as Jamkesmas members to get equal treatment in using healthcare service.

The difference of opinion between the two researchers is generated by the difference of treatment by health workers to patients. Hospitals as healthcare service providers should not give different services based on the payment methods of the patients either insurance users, BPJS or Jamkesmas. Patients of Jamkesmas or Aid Recipient have similar opportunity to use healthcare service without making a distinction of the healthcare service. In addition, patients who do not have any insurance however they get similar service, treatment and procedure with the insurance users, are likely to feel less satisfied with the healthcare service.

The result of path analysis also showed that there was an indirectly positive association between type of insurance through quality of service toward patients' satisfaction of inpatient care in RSUD Dr Moewardi and statistically significant. The study is in accordance with Zarei et al., (2012) that states patients without insurance coverage have low perceived quality. Patients without insurance pay the hospital bill out-of-pocket, they expect hospitals are able to fulfill their expectation. Lestari et al., (2016) states that non insurance patients have higher level of satisfaction compared to patients with health insurance. It is because of the difference of treatment in which patients who self pay or out-ofpocket is likely to be noticed about their needs and ailment.

\section{G.The influence of type of class of in- patient care toward patients' satis- faction.}

The result of path analysis showed that there was a direct association between type of class of inpatient ward toward patients' satisfaction. The association is positive and statistically significant. It means that healthcare service quality delivered to class III patients is in the lowest level. On the other side inpatient care in class I deliver the best service compared to class II and class III. Patients are relatively less satisfied with healthcare service in class III since their 
Journal of Health Policy and Management (2017), 2(1): 1-15

https://doi.org/10.26911/thejhpm.2017.02.01.01

expectations toward healthcare service are not fulfilled. In general, the difference of class in hospitals is distinguished by facilities as well as type and price of medicines given. In addition, there is a missed perception which has been entrenched within the healthcare service providers' mindset that prioritizing more the patients in class I ward than patients in class II and III. The type of class III of inpatient ward is generally patients with relatively low level of income and education, thus it certainly needs more skillful service especially in communicating anything related to patients' right and responsibility (Nurrizka dan Saputra, 2011). Therefore it can be concluded that the influence of type of class is directly and positively associated with patients' satisfaction accordingly the result of the study can be affirmed as in accordance with the study above.

The study also showed that in path analysis there was indirectly positive association and statistically significant between type of class of inpatient ward though quality of service toward patients' satisfaction of inpatients care in RSUD Dr Moewardi. It is in accordance with Asshidin et al, (2016) who states that quality is influenced by value of product characteristics. In healthcare terms, one of them is type of class of inpatient ward. Every type of class of inpatient ward offers different facilities, procedures and convenience, so that every class has distinguished quality.

\section{H. The influence of quality of service toward patients satisfaction.}

The result of path analysis showed that there was direct influence between inpatient service qualities toward patients' satisfaction. The association was positive and statistically significant. Quality of service in the study used servqual method which consists of tangible, responsiveness, reliability, assurance, and empathy. Kim et al.,
(2017) states that quality of service is proven to have positive effect toward patients' satisfaction. Quality of service will make patients feel satisfied. In addition, comfortable environment, extensive facilities, and pleasant service for the treatment in hospitals are the aspects of service quality which are important within satisfaction. (Zarei et al., 2012).

Some studies show doctors' and nurses' performance are other important factors within patients' satisfaction (Butt and Run, 2010). The emergence of trust enables patients to feel satisfied with the convenience given. Professional and timely services as well as appropriate information given are what patients expect from hospitals. Quality of service delivered by hospital is especially determined by factors related with process such as scheduling, delivery of care, and accuracy of information given (Kim et al., 2017).

RSUD Dr Moewardi is one of the referral hospitals, there are numerous patients who are severely ill, therefore fast respond of the personnel in delivering services leads to the increasing of satisfaction level. Increasing patients' satisfaction RSUD Dr. Moewardi should maintain the quality of healthcare service so that patients will feel very satisfied with the delivered healthcare service quality.

Based on the result of the study it can be concluded that patients' satisfaction is influenced by family income, level of education, length of stay, doctors' salary, doctors' working period, type of insurance, type of class and healthcare service quality. Quality of service is influenced by family income, length of stay, doctors' working period, type of insurance, and type of class.

\section{REFERENCE}

Andaleeb SS, Siddiqui N, Khandakar S (2007). Patient satisfaction with 
health services in Bangladesh. Health Policy and Planning, 22:263-273

Anjaryani WD (2009). Kepuasan Pasien

Rawat Inap Terhadap Pelayanan Perawat di RSUD Tugurejo Semarang. Tesis. Program Pascasarjana Universitas Diponegoro Semarang.

Asshidin NNH, Nurazariah A, Bashira BH (2016). Perceived Quality And Emotional Value That Influence Consumer's Purchase Intention Towards American And Local Products. Procedia Economics And Finance. 35: 639-643.

Bakar C, Akgün HS, Al Assaf A (2008): The role of expectations in patients' hospital assessments: A Turkish university hospital example. Int $\mathrm{J}$ Health Care Qual Assur. 21: 503-516.

Bardach NS, Wang JJ, Leon SFD, Shih SC, Boscardin WJ, Goldman LE, and Dudley RA (2013). Effect of Pay for Performance Incentives on Quality of Care in Small Practices with Electronic Health Records: A Randomized Trial. Journal of the American Medical Association. 310(10): 1051-9.

Boer DD, Delnoij D, Rademakers J (2010). Do patient experiences on priority aspects of health care predict their global rating of quality of care? A study in five patient groups., Health Expect. 13:285-97

Braveman P, Egerter S, Barclay C (2011). Exploring The Social Determinants Of Health. Robert Wood Johnson Foundation Commission to Build A Healthier America. 12: 4

Butt MM, Run ECD (2010). Private healthcare quality: applying a SERVQUAL model. Int $\mathrm{J}$ Health Care Qual Assur. 23(7):658-673.

Borghans I, Kool RB, Lagoe RJ, Westert GP (2012). Fifty ways to reduce length of stay: an inventory of how hospital staff would reduce the length of stay in their hospital. Health Policy.

Calnan M, Rowe R (2006). Trust relations in the 'new' NHS: Theoritical and methodological challenges. Departement of Social Medicine: University of Bristol. Retrieved from https://www. kent.ac.uk/scarr/publications/Wk Paper14(1)CalnanRowe.pdf

Deng Z, Lu Y, Wei KK, Zhang J (2009) Understanding Customer Satisfaction and Loyalty: An Empirical Study of Mobile Instant Messages in China. International Journal of Information Management. 30:289-300.

Dengjuin L, YaHsin L, JarYuan P, IngCheau S, Glen R, MingJen C (2009): Chronic kidney-disease screening service quality: questionnaire survey research evidence from Taichung City. BMC Health Serv Res. 9: 239-10.

Dwiyanto A (2010). Manajemen Pelayanan Publik: Peduli, Inklusif, dan Kolaboratif. Yogyakarta: Gajah Mada University Press.

Faizin SN, Mukeri M, Fathoni A (2015). Analysis Tangibles, Reliability, Responsiveness, Empathy Assurance And Image Of Hospital And Interest Back To Use The Service General Hospital Of Poly Ungaran. Journal of Management, 1(1): 2502-7689.

Fletchera JM, Frisvol DE (2012). Higher Education and Health Investments: Does More Schooling Affect Preventive Health Care Use?. 2: 144-176.

Fraihi KJA, Famco D, Famci F, Latif SA (2016). Evaluation of outpatient service quality in Eastern Saudi Arabia Patient's expectations and perceptions. Saudi Med J. 37(4): 420-428.

Hafizurrachman (2009). Kepuasan pasien dan kunjungan Rumah Sakit. Jurnal Kesehatan Masyarakat 4(1). 
Journal of Health Policy and Management (2017), 2(1): 1-15

https://doi.org/10.26911/thejhpm.2017.02.01.01

Haviland MG, Morales LS, Dial TH, Pincus HA (2005). Race/Ethnicity, Socioeconomic Status, and Satisfaction With Health Care. Am J Med Qual. 20 (4): 195-203.

Herqutanto, Basuki B,Jauzi S, Mansyur M, (2011). Pengetahuan dan Keterampilan Komunikasi Dokter Pasien dan Faktor-faktor yang Memengaruhinya. J Indon Med Assoc. 61(5): 195-199.

Irawati N, Primadha R (2008). Pengaruh Kualitas Pelayanan Terhadap Brand Image Pada Unit Rawat Jalan Poliklinik Penyakit Dalam Rsu Dr. Pirngadi di Medan. Jurnal Manajemen Bisnis: 1(2):1978-8339.

Kawachi I, Adler NE, Dow WH (2010). Money, schooling, and health: Mechanisms and causal evidence. Ann N Y Acad Sci. 1186:56-68.

Khoung MN, Anh HTH (2013). Direct and Indirect Effects of Customer Satisfaction through Product and Service Quality-A Study of Phu Nhuan Jewelry Stores in Ho Chi Minh City, Vietnam. Journal of Economics, Business and Managemen, 1(3): 285-290.

Kim CU, Shin JS, Lee J, Lee YJ, Kim M, Choi A, Park KB (2017). Quality of medical service, patient satisfaction and loyalty with a focus on interpersonal-based medical service encounters and treatment effectiveness: a cross-sectional multicenter study of complementary and alternative medicine (CAM) hospitals. BMC Complement Altern Med. 17:174.

Krishnasamy M, Wilkie E, Haviland J (2001). Lung cancer health care needs assessment: patients' and informal carers' responses to a national mail questionnaire survey. Palliat Med, 15: 213-27.

Kurtz S, Silverman J, Draper J (2005) Teaching and learning communicati-

on skills in medicine. 2nd ed. Oxon: Radcliffe Publishing Ltd

Lestari WP, Sunarto, Kuntari T (2016). Analisa faktor penentu tingkat kepuasan pasien di Rumah Sakit PKU Muhammadiyah Bantul. Jurnal Kedokteran dan Kesehatan Indonesia.

McMichael C, Healy J (2017). Health equity and migrants in the Greater Mekong Subregion. Glob Health Action. 10(1): 1271594 .

Mulyawan B (2015). Kualitas Pelayanan Rumah Sakit Umum Daerah (Studi Tentang Kepuasan Pasien Rawat Inap Peserta Jamkesmas Pada Rumah Sakit Umum Daerah Kabupaten Indramayu). Jurnal Aspirasi. 5(2): 1-14.

Nurfauzi M (2013). Studi Tentang Kualitas Pelayanan Kesehatan dalam Memberikan Kepuasan Masyarakat Pada Puskesmas Desa Genting Tanah Kecamatan Kembang Janggut Kabupaten Kutai Kartanegara. eJournal Administrasi Negara. 1(1): 268-281.

Nurrizka RH, Saputra. Index Of Society's Satisfaction Toward Health Service. Jurnal Manajemen Pelayanan Kesehatan. 14 (1): 11-19

Oroh ME, Rompas S, Pondaag (2014). Faktor-Faktor yang Berhubungan dengan Tingkat Kepuasan Pasien Rawat Inap Terhadap Pelayanan Keperawatan di Ruang Interna RSUD Noongan. Jurnal Keperawatan. 2(2): 1-7.

Peraturan Menteri Kesehatan Republik Indonesia Nomor 39 Tahun 2016 Tentang Pedoman Penyelenggaraan Program Indonesia Sehat Dengan Pendekatan Keluarga. Diakses dari http://www.depkes.go.id/resources/d ownload/lain/PMK_No.39_ttg_PIS_ PK.pdf pada 21 Mei 2017.

Sinambela, Lijan P (2006). Reformasi Pelayanan Publik. Bumi Aksara: Jakarta. 
Akbar et al./ The Influence of Personal Factors of the Patient, Doctor, Payment Method

WHO (2009). Technical Brief for PolicyMakers. Department of Health Systems Financing.

Zarei A, Arab M, Froushani AR, Rashidian A (2012). Tabatabaei SMG. Service quality of private hospitals: the Ira- nian Patients' perspective. BMC Health Serv Res.12(1):31. 